\title{
プラスチック構成材料評価の基準（抄訳）
}

\author{
その 2 \\ 訳者。稻井 \\ 猛 $^{*}$

\section{Basic Criteria for Evaluating Some Plastic Materials of Construction}

\author{
Raymond B. Seymour
}

Corrosion, 10, No. 1, 37 47 (1954) Jan.

\section{可塑 性 化 硫 黄}

硫黄は通常プラスチックス材料とは考えられないが, 加熱すると延性を生じ成型可能となるので, プラスチッ クスとしての要求がある程度滿たされる。この種商品に は硫黄の化学的抵抗性を備光, 少くとも25年の耐久性を 有するものもあり, 且つ強度と延性の改善もあって有望 である。製品の多くは 50～60\%の硫黄を含み, 残部は 主として等級分けしたシリカまたは炭素の凝結物, 分散 剤および可塑剤より成っている。カーボンブラックは通 常セメントが融解状態にある時, 配合物が沈積するのを 少なくするために添加せられ，ポリオレフィン硫化物な どの可塑風は延性を与えるために用いられる。この延性 は主として可塑㶡の配合率によるもので, それを増減す ると広い範囲で変化し,例えば第 1 図に示すよ $5 に, 1 / 8$ in直径の針を一定の深さだけ押し込めるに要する力は可 望剤の含有率に逆比例的関係となる。

硫黄は $96^{\circ} \mathrm{C}$ で斜方系結晶から単斜系に変態し, 比重 が変化するので, この臨界温度以上では硫黄セメントは 使用出来ない。その外, 硫黄は多くの有機溶䶒に可溶性 であり，またアルカリ性溶液に侵されるので, 多くの溶 昘の存在乃至 $\mathrm{pH}$ が 10 以上の場合には利用できない。 硫黄は酸化されて二酸化硫黄になるので強い酸化性媒体 で使用することもできないが，非酸化性の酸や塩類に対 しては完全に抵抗性がある。

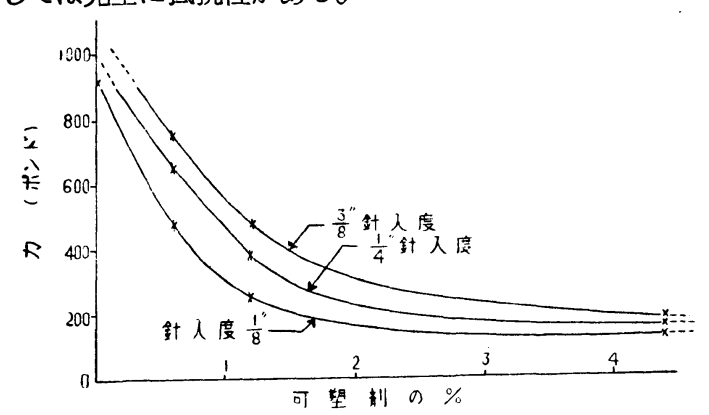

第1図 硫黄セメントに和ける可塑刜の含有率 と延性との関係

試監は㨁徑 $1 / 8$ in の針を $1 / 8,1 / 4$ in および $3 / 8$ in の梁さまで押込むに要する力を $1 \mathrm{~b} て ゙$ 測 定したものである

* 日本雪信曘話公社 電父通信研究所
ポリエチレン

ポリエチレンは化学構造の観点からは最も簡単なプラ スチックスの1つであるが, 標準の重合技術では製造で きない。ボリエチレンは Faucett およびその共同者に よりエチレンを少量の酸素の存在で圧力を加えて重合さ せることにより始めて作られた。化学的抵抗性は経験的 法則より考え, ポリエチレンは常温で化学薬品に対し最 も耐える材料の 1 つであることが指摘される。この化学 的抵抗性と製法の面より考え, 将来は最も重要なプラス チックスであることが予言される。

ポリエチレンは分子量の高いパラフィンと考えること ができる。水に溶解することが極めて少く，比重は小で 電気絶緣性が良く, 多くの酸、アルカリ扎よび塩類に耐 え, 種々の有機溶剤に対し膨潤することはあっても完全 に溶解することはない。

酸化エチレンの重合体類はポリエチレンに比し, エー テル結合であることと, 未端に水酸基を持つことが相異 している。ポリエチレン・グライコール等のこの種製品 は極性が増大しているので, 水に可溶性であり, 化学的 抵抗性構成材料には使用されない。

\section{ポリイソブチレン}

ポリイソブチレンは1873年から知られていたが, 1937 年 Otto 扰よび Mueller-Cunradi が特許権を得て始め て高分子量の商品が製造されるに至った。ポリイソブチ レンは塩化アルミニウム又は三弗化硼素の存在でイソブ チレンを $-100^{\circ} \mathrm{C}\left(-148^{\circ} \mathrm{F}\right)$ の低温で重合させ製造さ れる。他の添加重合反応による高分子製品も低温で例兄 ば分子量的 10,000 のものは $-10^{\circ} \mathrm{C}\left(14^{\circ} \mathrm{F}\right), 200,000$ は $-100^{\circ} \mathrm{C}$ で作られる。

第1表の式から証されるように, ポリイソブチレンは ポリエチレンの構造に全く類似している。しかし重合体 の鎖にメチル基があるので彈性が増加し, 化学的抵抗性 が幾分少い。ポリイソブチレンは熱に抵抗性少く, 粘着 性であるから,アメリカでは先ず接着荗とチューインガ ムに利用されたが，ドイッでは炭素を配合してタンクの 内張りに応用された。

\section{アスファルト}

アスファルトは天然品で, 近代的構成材料が実用化さ 
れる数世紀前から使用されていた。天然に産出するギル ソナイト,グラハマイトおよび光沢性ピッチのようなア スファルトと石油系のものとを区別しよ5として定義等 に若干の論争がある。簡単にいえばアスファルトは一種 のコロイドで, 二硫化炭素に可溶性の多環式化合物と小 量の炭素とよりなる。多くのアスファルトは若干の酸性 成分を含み, 従って苛性ソーダには侵されるが, 非酸化 性の酸や㢁蝕性塩類には抵抗性がある。第 1 表の式から 推論される通り濃硫酸および稀硝酸には侵される。この 構造は極めて複雑であり，式で正確に指示することは困 難である。

アスファルト類のうち最も広く利用されているのは石 油の残留分に基づくもので, 個々の組成は原油の起源に 依存する。また最子古い天然産の 1 つはトリニダード湖

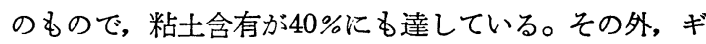
ルソナイト, 光沢性ピッチ, ラファエライトおよびグラ ハマイト等が天然品である。エラテライト並びにウルチ ライトは外のアスファルトと化学的性質は類似している が有機溶剩に溶け難い。一般に信ぜられている処に反し, 合成アスファルトは天然のものと利用度は余り相異がな い。物理的乃至化学的定数が, その根源に関するデータ よりはるかに有意義である。

アスファルト類は有機溶液，水性分散液および，配合 物を用い，または用いずに融成物として使用される。最 あ使用量の多いのは道路工事と防水処理であるが, 化学 的構成材料にる相当量用いられる。

\section{コールタール・ピッチ}

コールタール・ピッチは石油アスファルトと同類に分 類されるであろ5。勿論, その成分は不定で, 化学的並 びに物理的性質は製造中の蒸溜程度により広く变る。コ ールタール・ピッチは芳香族炭化水素より成り, 環状パ ラフィン類より成るアスファルトとは化学的組成が本 質的に異っている。しかし, 両者の物理的性質は或程

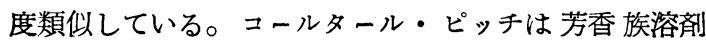
に僅かに可溶性で,アスファルトより熱には安定性が少 W。

アスファルトと同様コールタール・ピッチは有機溶偊 の溶液, 水性乳濁液および熱融解物として使用される。 この主な用途は配合填隙䑤で, 高価でないるのは塗料に 利用され，管路の防護に相当量使用される。

\section{クマロンーインデン樹脂類}

クマロンおよびインデンはコール・タールのナフサよ り分離され, 硫酸の存在で重合して樹脂化されるもので, これは 1890 年 Kraemer および Spilker が指示した 処である。しかしこれらのものが商品化したのは1920年 以後で, 現在では年産 $20,000,000 \mathrm{lb}$ 以上に達している。 ポリクマロンおよびポリインデンの構造式が第 1 表で別
々に与えてないのは, 多くの商品が両者の共重合体にな っているからである。

クマロンーインデン樹脂は融解し易く, 多くの溶剤に 溶ける。ゴムへの配合, ワニス, 床タイルおよび印刷イ ンキ等に広く用いられる。これらの樹脂は多くの非酸化 性酸, 塩類扣よびアルカリ類には抵抗性を有するが, 化 学的抵抗性柈成材料に広くは使用されない。

\section{ポリスチレン}

スチレンは 1839 年に Simon が始めて重合させたが, 1 世紀以上も実験室的知識の域を出ず, アメリカでは, 1937年に商業的となった。今日ではべンゼンとエチレン からスチレンを合成し，これを重合する方法で多量製造 されている。ポリスチレンはその構造から推論されるよ うに, 極性の大なるアルコール・グライコールのような 溶剤を除き多くの有機溶剤に可溶性である。非酸化性 酸, 塩類およびアルカリには完全に抵抗性があるが, 塩 素,クロム酸, 硝酸扎よび濃硫酸には侵される。これは 比重が小さく, 吸湿性少く, 誘電的性質が優秀である。 この主な欠点はもろいことで, その為に化学的抵抗性構 成材料への利用が制約される。しかしこの久点は次の論 述で明らかになるが, 重合を改善することにより克服せ られた。

\section{スチレン共重合体類}

最も広く使用されるスチレン共重合体は 20 亿 $40 \%$ の ブタジェンと 15〜30\%のアクリロニトリルとを含むも のである。構造式から推論されるように,ブタジェンの 化学的抵抗性はポリスチレンと殆んど同じであるが, 可 撓性を備え,その共重合体はもろさが著しく改善される。 これは水性ペイントのように水の乳状液乃至有機溶液と して保護塗料に広く使用される。

スチレンとアクリロニトリルとの共重合体はポリスチ レンより衝撃に強いが, 酸やアルカリ類に幾分か抵抗性 が劣る。これらの共重合体は通常アクリロニトリル・ゴ ムと混ぜ合せ, 㣫撃抵抗性を改善して使用される。この 混ぜ合せもの>化学的抵抗性は共重合体と本質的に同じ である。この混ぜ合せるのは広くプラスチックスのパイ プに使用せられ，溶蝺溶接や機械的接合のプラスチック ス構成材料にある程度使用される。

\section{アクリル榭脂類}

アクリル樹脂の商業化はドイッならびにアメリカたお いては Rohm の努力に依るところが大きい。この樹脂 は幾分ゴム状で，化学的抵抗性構成材料には稀に使用さ れる。塩類にはよく抵抗し，酸類には可なり耐えるが， アルカリ類には鹼化され易い。ポリアクリル酸就よびポ リメタクリル酸は水に可溶性で化学的抵抗性構成材料に は使用されない。

$$
\text { メタクリル樹脂は固く，恐らく立体障害により襝化さ }
$$


第 1 表 プラスチックスの分子構造と化学的抵抗性

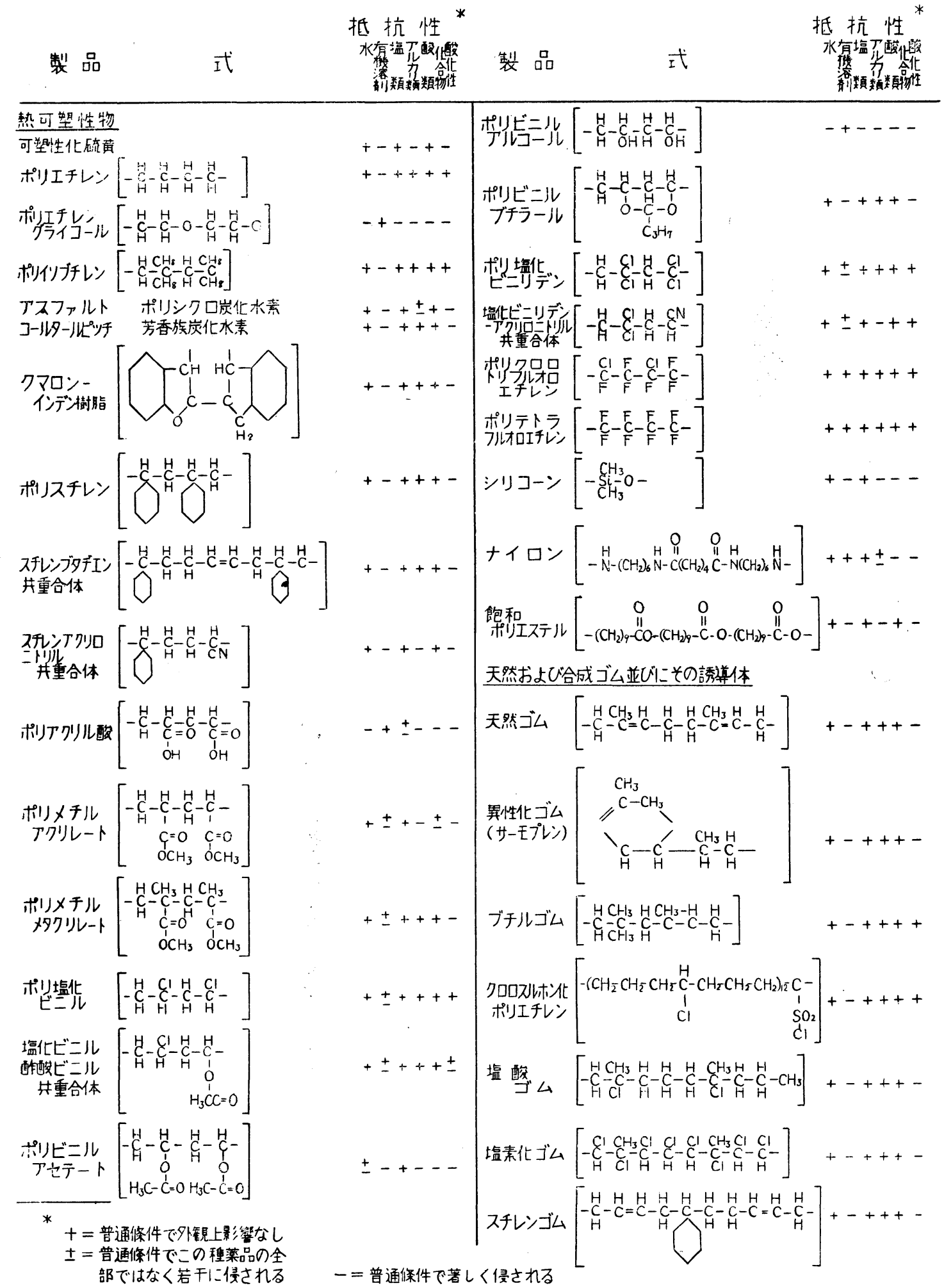




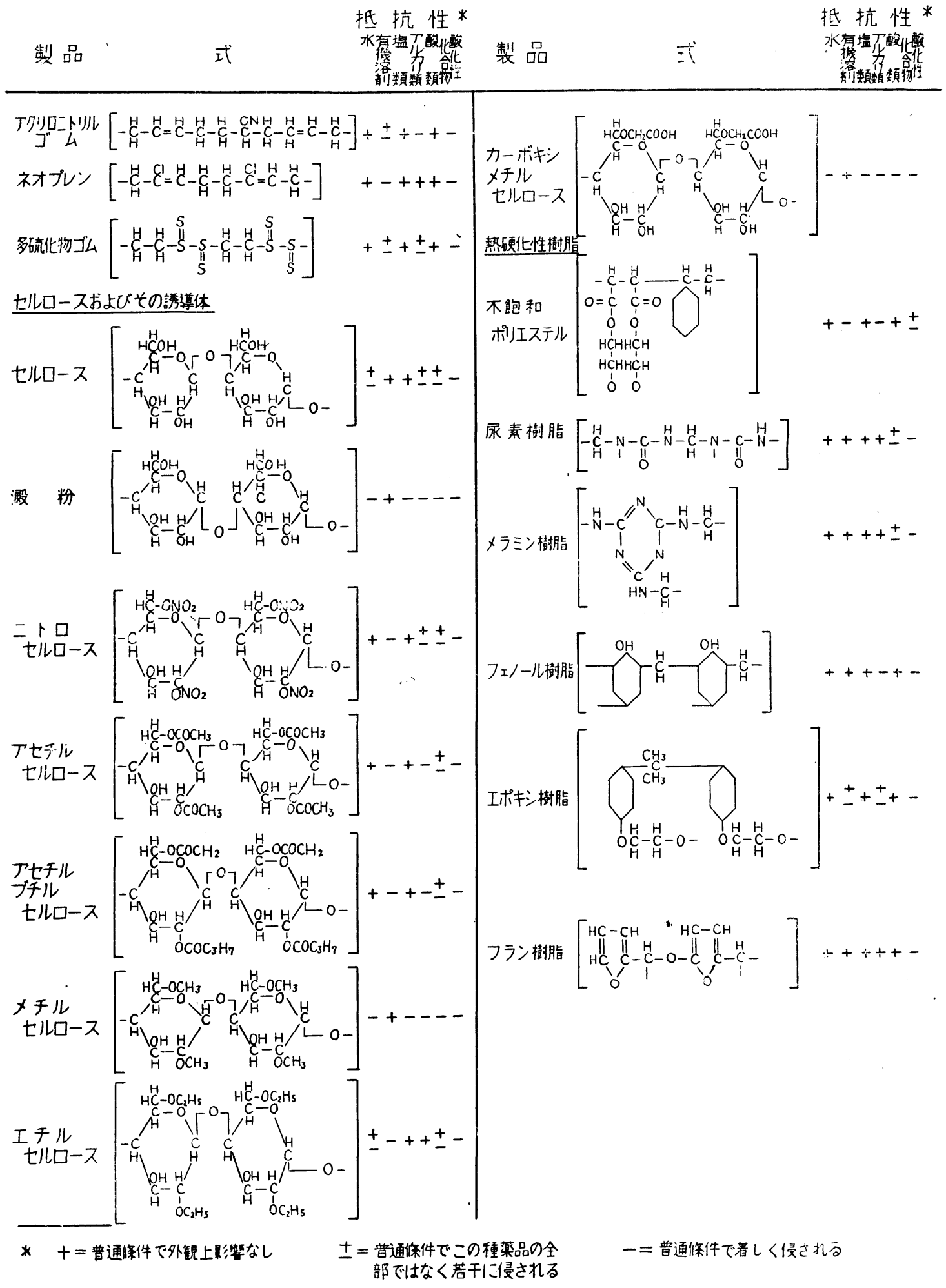


れがたい。これは例えばポリメチル・メタクリル樹脂の ように透明なシートとして有用で，透明なプラスチック 又製品の必要な場合の化学的抵抗性構成材料に使用され る。メタクリル樹脂の溶液は保護塗装にある程度用いら れる。ポリメチル・メタクリル樹脂の透明板は溶剂乃至加 熱による接合で成型装置としてメッキ工業に使用される。

\section{ポリ塩化ビニルおよび共重合体類}

ポリ塩化ピニルは 20 世紀の初めに打ける Ostromysslenskii の研究に基づき発展したものが多い。1930 年頃 までは適当な可塑剤がないので，商業的製造はなかった。 意外なことには可塑性化しないもの小優秀な利点が認め られる前に，可塑性化せらるべきポリ塩化ビニルが約 10 億 $\mathrm{lb}$ る製造された。

固い可塑性化しないポり塩化ビニルと可塑性化する前 の通常のポり塩化ビニルとの相異は第一には分子量の差 で，分子量の分布も異る。両者は本質的には同じ構造式 であり化学的抵抗性も同じである。しかし，化学的抵抗 性装置に利用する時，押出しができるようにするため， 可塑性化しなければならぬので多少酸化性薬剤に対して は抵抗性が低下し，耐熱性も変る。その外，非酸化性酸， アルカリ，㙁類等に対しては同様に抵抗性がある。

可塑性化の外に，共重合により特性が相当改善された。 このタイプで最も広く使用されるのは塩化ビニルと小量 の酰酸ビニルとの共重合体である。酢酸基は製品の化学 的抵抗性を低下させるが，13\%までは多くの用途で差支 えない程度に十分な抵抗性がある。

可塑性化しない固いポり塩化ビニルは第一に押出しパ イプに，その外加熱融着の熱可塑性構成材料に用いられ る。可塑性化したものは機㭜的物品およびシート張りに 使用される。不溶解性のため塗料としての用途が限定さ れ，オルガノゾル或はプラスチゾルのよ5な特殊の処方 による。㙁化ビニルと酭酸ビニルとの共重合体は溶液と してよく使用され，通常ビニル叙装と称せられている。

\section{ポリビニル・アセタール類}

ボリビニル・アセテートは 1920 年より商業的に製造 されその $2 \sim 3$ 年前に Klatte と Rollette が実用化し た技術が採用されている。これは酸やアルカリで極めて 加水分解し易く，吸湿率が大きいので，耐蝕性構成材料 に広くは使用されない。この水性分散液と水性接合剤と の混合物は一枚石床の塗料に提唱されている。

ボリビニル・アセテートを歔化すると水に可溶性のポ リビニル・アルコールが出来る。この製品は耐溶剤性の 管やガスケットにしばしば使用される。これら製品の耐 水性はホルムアルデヒドと表面反応させることにより改 善される。

ポリビニル・アルコールとブチルアルデヒドの如き高 分子量のアルデヒドとの反応でアセタール類を生じ, こ
れは水に不溶性でかなりの化学的抵抗性がある。ポりビ ニル・ブチラールは標準ヨッシュ・プライマーに用いら れる。

\section{塩化ビニリデン重合体類}

塩化ビニリデンおよび塩化ビニル並びにアクリロニト リルとの共重合体類はサランという総称で使用されてい る。構造式で示されているよ5に，塩化ビニリデンは塩 化ビニルと相似的であるが，塩素群が 2 倍ある。塩化ビ ニリデンの重合体類拉よび他の化学的抵抗性のあるるの との共重合体類は多くの非酸化性酸,アル゙リおよび塩 類に抵抗性がある。

サラン共重合体類は可塑性化して炭素を配合し，可撓 性シートが作られる。この製品は硬質性重合体より化学 的抵抗性が少なく，加熱アルカリ溶液用には推獎されな い。塩化ビニリデンはスパイプ，筒，辨等に使用せられ， 水性分散液, 並びに溶液として保護塗装に用いられる。

\section{ポリフルオロエチレン}

ポリクロロトリフルオロエチレンおよびポリテトラフ ルオロエチレンは相当するポり塩化ビニルより高価では あるが，酸化剤，溶凨，高温度に耐える利点がある。゚ リテトラフルオロエチレンはポリクロロトリフルオロエ チレン重合体より幾分抵抗性は大ではあるが，両者共ガ スケット, 隔膜, 辨, シートおよび機械部品等の特に化 学的抵抗性の要求されるるのに広く使用される。両製品 とも, $200^{\circ} \mathrm{C}\left(400^{\circ} \mathrm{F}\right)$ 程度の温度でしかも硝酸の存在に おいてさ光使用され成功している。ポリテトラフルオロ エチンンは熔融アルカリ金属および高温弗素の外，殆ん どあらゆる薬剤に耐える。これらはモルド，押出し部品 並びに水性分散液として有效である。水性分散液は各種 金属表面を熱処理して，非接着性表面とするのに応用さ れている。

\section{シリコーン 類}

シリコーン・プラスチックスは他のあらゆるプラスチ ックスと異り, 基本分子の炭素原子の代りに珪素を含ん でいる。予想されるように，このプラスチックスは熱に 対し特に耐える。ある製品は $200^{\circ} \mathrm{C}\left(400^{\circ} \mathrm{F}\right)$ を超す温 度で連続使用されていると報告されている。この製品は アルカリと溶剤類には抵抗性が少ないが，非酸化性酸に はかなり耐える。化学的抵抗性構成材料の主な利用はガ スケット材料や，高温度抵抗性の塗裝等である。

\section{ポリアマイド類}

ポリアマイド・ブラスチックスは 1899 年に Gabriel と Manesにより，初めて認められ，アミノカプロン酸 を加熱して、この形式のものを得た。この種反応は Carothers により更に研究せられ，アジピン酸とへキサ メチレン・ジアミンを縮合させてナイロンを実用化した。 ナイロンは加熱した蟻酸、酷酸および石炭酸を除き多く 
の溶剤に不溶性である。またこれは腐蝕性の塩類には耐 えるが，高温の酸およびアルカリには加水分解される。 ポリアマイド類は化学工業で耐蝕性材料としては広く利 用されてはいない。

\section{天 然ゴム}

構造式を見て予想されるように，天然ゴムはアルカリ， 痛蝕性塩類或は非酸化性酸類には侵されないが，例外と して塩酸は二重結合の所に附加反応が起る。天然ゴムは 植物性及び礦物性のガソリン, ベンゼン並びに四塩化岸 素のような非酒性溶剤の存在では滿足には使用されない。 㕛硝酸, 濃硫酸, クロム酸, 次覀塩素酸ソーダ並びに二 酸化塩素のような酸化性物質の存在では使用されない。 無加硫のゴムは常温で流れを起すが，加硫した軟質ゴ ムは $66^{\circ} \mathrm{C}\left(150^{\circ} \mathrm{F}\right)$ までの温度では十分使用に耐える。 硬質ゴム即ちエボナイトは酸化される二重結合が殆んど ないので，熱攻び薬剤に抵抗性がある。

加硫天然ゴムゔ固有の化学的抵抗性を持つことは多年 にわたり知られて尔り，1925年迄にホース，管及びガス ケットのような機械的物品に利用されているが，ゴムと 鋼との接着方法が十分でないので，広く化学的抵抗性構 成材料に利用古るには久けていた。この目的のため最初 に滿足な接着㓣を作ったのは Fisher で，天然ゴムを有 機スルホン酸の存在で加熱しサーモプレンと称する多環 式のゴムを製作した。

構造式で代表的に示されているようにサーモプレンは 天然ゴムと同様の化学的性質を有する。しかし，加硫が できないので流れを起す傾向がある。この点では天然ゴ ムよりもむしろシェラックに似ている。サーモプレン並 びに最近の改善接着用はゴムシートと鋼との接着によく 使用されている。

ゴムはラテックスやラテックスと水性接合剤との混合 物，また軟質ゴム並びに硬質の加硫ゴム等として使用さ れる。この後の 2 つが化学工業の装置に利用される天然 ゴムの主な応用面で, タンクの内張, ガスケット, ホー ス，管および継手等として用いられている。

\section{ブチル・ゴム}

ポリイソブチレンの主な欠陷の 1 つは, 熱に耐えない ことである。この久点を幾分改善したのは Thomas, Lightbown, Sparks, Frölich 及び Murphee で，イソ ブチレンとイソプレンとを共重合させ，いわゆるブチル ・ゴムを作った。これは加硫が可能である。ブチル・ゴ ムの構造式妾考察する時, イソプレン群は全体の構造式 の中 1 〜 $\%$ で, 残部はポリイソブチレン群であること は注意を要する。流れに対する抵抗性を除き，加硫した ブチル・ゴムはポリイソブチレンと化学的抵抗性が本質 的に同等でかる。

\section{クロロスルホン化・ポリエチレン}

式で示されているように，クロロスルホン化ポリエチ レンはポリエチレンと塩素および二酸化硫黄とを反応さ せて得られる製品である。この誘導体はポリエチレンの 多くの性質を有しているが，相当極性がある。即ち金属 表面に容易に接着し，耐熱性も柏当大きい。活性団が存 在するのでこの製品は一酸化鉛のような塩基性化合物に より加硫が可能であり, 多くの溶刜, 㙁類, 酸, アルカ リおよび酸化剤等に対し $100^{\circ} \mathrm{C}\left(212^{\circ} \mathrm{F}\right)$ の温度で抵抗 性のあるゴム状物質が作られる。この製品は新らしいの で未だ経験に基づくデータが少いけれども，クロロスル ホン化ポリエチレンは以前から要望されていた点を充す 見込がある。

\section{壏酸 ゴム}

塩酸ゴムは構造式で十分代表されている。塩酸に曝露 される部分のゴム張り等に偶然用いられるのを除き，化 学的抵抗性構成材料として使用されることは殆んどない。 塩酸ゴムは式から予想されるように，有機溶剤に溶解性 大きく，天然ゴムよりはるかに彈性が劣る。

\section{塩 素化ゴム}

塩素化ゴムは 1801 年に Roxburgh により始めて作 られたが, Englehard, Day 並びに Havemann が独立 にこのゴム誘導体を作る特許権を得て，1859年に商業的 に製造されるに至った。その後 1915 年には保護塗装に 使用せられ，他の多くの合成品より早く商用化した。塩 素化ゴムは非彈性的製品で多くの有機溶剂に可溶性であ る。構造式で分るよ $5 に$ に, 天然ゴムと同様, 非酸化性塩 類,アルカリ扣よび酸に耐える。二重結合が天然ゴムよ り少いので酸化剤に対しては抵抗性が大きい。

塩素化ゴムの主な用途は保護塗装と接着耠である。こ れを押出しパイプやモルドのプラスチックスとして使用 する企は熱安定性が元来乏しいので見込がない。

異性化ゴム即ち環式化のゴムは接着䬉や保護塗装に使 用されたが，その大部分はスチレン・ブタジェン共重合 体で置き換えられた。

$$
\text { スチレン・ゴム }
$$

スチレン・ゴムはブナ $\mathrm{S}$ 或は $\mathrm{G} \mathrm{R}$ - S とも称せられ合 成ゴムの中で最も広く使用されている。しかし，化学的 抵抗性構成材料に応用されるのは天然ゴムよりは柏当少 く，工業上は後者の方が聞きなれている。

構造式を見て予想されるように，スチレン・ゴムはア ルカリ, 酸, 塩類および溶剂に対する抵抗性は天然ゴム に全く類似する。物理的性質は天然ゴムより幾分劣って いるが，この短所は製造方法の改善と配合の技術で克服 される。

アクリロニトリル・ゴム

アクリロニトリル・ゴムはブナ $\mathrm{N}$ 或は $\mathrm{G} \mathrm{R}$ - $\mathrm{A}$ とも称 せられ，耐油性が本質的に要求される場合に化学的抵抗 
性構成材料に使用される。またポり塩化ビニルとスチレ ンーアクリロニトリル共重合体などは, 低衝撃性重合体 の配合剤として広く使用される。これはシアノ基を含ん でいるので，天然拉よび合成ゴムよりアルカリに対する 抵抗性が少く酸と㙁類に対してはよく耐える。

\section{ネオプレン}

ネオプレンは 1931 年に Carothers によりビニル・ア セチレンより始めて作られた。ビニル・アセチレンおよ びその関聯化合物類はこれより前 Nieuwland によりア セチレンから合成されていた。構造式で示されているよ うに, ネオプレン即ちポリクロロプレンは天然ゴムと化 学的に関聯がある。メチル基の代りに塩素を置換すると 植物性攻び礁物性油に対し抵抗が増大し，耐久性と而熱 性が改善される。天然ゴムと反応する塩酸並びにこれに 類似の化合物は事実ネオプレンに滲み込むので, ネオプ レン張りは塩酸乃至弗酸等の存在では推獎されない。二 酸化鉛およびこれに類似の加硫剤と共に加慾すると，ネ オプレンは他のすべての非酸化性酸, 塩類およびアルカ リ類に対し抵抗性となる。

ネオプレンはホース, その外機械的物品, シート㲀り, パテ状の接合凧, 防護塗装和よび水性分散液として有効 である。シート状のネオプレンは化学的抵抗性構成材料 として天然ゴムのよ 5に広くは使用されないが，耐油性 の要求される特殊の用途には推獎される。ネオプレンは 固体分の多い溶液が得られるので，化学工業に括ける上 質の保護塗装として相当利用が見出されている。この塗 装は常温で加硫が可能で，高彈性の塗膜となり，沸騰水 の温度でも流れの起らぬものが得られる。

\section{多硫化物ゴ}

多硫化物系のゴムは 1932 年 Patrick により多硫化》 ーダとエチレン・ジクロライドのようなジクロル化合物 とを縮合せしめて実用化されたるのである。この製品は 幾分ゴム状で溶剤に対する抵抗性は著しい。多少の臭気 はあるが，塩類拉よび非酸化性酸によく耐え，アルカリ にる可なり抵抗性がある。

多硫化物ゴムは室温で固化する液体として，また水性 分散液拉よび固形のものを火物吹附けしてシートを作る 等の使用方法がある。液状重合体は耐溶刜性の船茹に用 いられる。固体は硫黄セメントの可塑剤に使用され，耐 溶刜性の機械類や火焰吹附け叙装で海水の装置に用いら れる。水性分散液は耐溶刜性のタンク内張りに供せられ る。

\section{セルローズ・エステルおよびエーテル類}

構造式からわかるように，纎維素はポリグルコシドで, ダイマーのセロビオーズが最す簡単な単位である。澱粉 もまたグルコーズの重合体であるが，その最も簡単なダ イマー単位はマルトーズで，七ロビオーズの異性体であ
る。天然のままの㵶維素は多年化学的抵抗性構成材料に 使用されている。木材は多くの塩類や溶剤に耐えるが， 酸やアルカリには徐々に侵される。その侵蝕率は原料木 材の種類により異る。

ニトロ・セルローズは 1845 年 Schönbきin が初めて 作り，1867 年に Hyatt が樟腦を使って可塑性化したも ので，塩類と或種の酸には耐えるが，アルカリに侵され る。またニトロ・セルローズは多くの溶剤に可溶性で極 めて然え易い。速乾性の塗料に広く使用されるが，防蝕 構成材料に多く用いられるのは見受けない。

アセチル・セルローズは 1865 年に Schutzenberger および Harden により始めて作られ, そのエステル溶 剂の溶液が第一次世界大戦の時, 飛行機のドープに使用 されたが, 20年の後, 始めてプラスチックスとして商業 的に有望のものとなった。その本来的な強勒性と可なり の耐焰性のために, アセチル・セルローズは化学的抵抗 性構成材料として広くではないが，モールドおよび押出 し部品等に工業的に使用される。

アセチル・ブチル・セルローズおよびその他の混命エ ステル類は容易に可塑性化され，またアセチル・セルロ 一ズより耐水性も良いので，化学工業に打ける簡易工事 のパイプ抽よ゙管の取付用として応用されている。アセ チル・ブチル・セルローズはアセチル・セルローズと同 様に塩類扣よび石油溶剂に抵抗性あるも，酸およびアル カリ用には推獎されない。アセチル・ブチル・セルロ ズの押出しパイプは石油工業に広範囲に使用され, また 水並びにガスの輸送にも若干使用される。

メチル・セルローズは 1905 年に Suida が研究所で 始めて作り, 数年の後 Dreyfus が商業量製造した。耐 水性に欠けるので化学的抵抗性構成材料には使用されな い。メチル・セルローズの最も商業的な応用は水に可溶 性である事を基とする場合である。

エチル・セルローズはメチル・セルローズよりは耐水 性がある。痛蝕性塩類には侵されないので, 金属類の保 護に加熱浸漬塗装として使用される。カーボオキシメチ ル・セルローズは水によく溶けるので化学的抵抗性プラ スチックスとして効能を考えるまでもない。

\section{ポリエステル 類}

饱和ポリエステル類は 1929 年 Carothers 及改び Arvin により初めて研究され,グライコール類と二塩酸類とを 反応せしめてプラスチックなるのが作られた。例えばコ ハク酸エチンンはコハク酸とエチレン・グライコールか ら得られた。

商業的ポリエステル類で最も簡単なるのはいわゆるア ルキッドと称せられ，1900年頃公表された文献に記述さ れている Smith のグリセリンと無水フタル酸との縮合 物の変型であって, Kienle はそれに続きオレイン酸の 
ような不飽和の脂肪酸を併用し焼付塗料を得るに至った。 この種ポリエステル類は装飾的塗装には広く使用される が耐蝕性構成材料には利用を見ない。

不飽和ポリエステルのプラスチックスは, 防蝕技術者 にはアルキッドより遥かに興味のあるもので Rust によ り, るっと後に改善されたものである。彼は無水フタル 酸の代りに無水マレイン酸のような不飽和無水物で置換 し, 得られた不饱和ポリエステルをスチレンと共重合さ せた。この製品はガラス繊維で補強して広く使用されて いる。これらのポリエステル類は非酸化性酸や腐蝕性塩 類に対してはよく耐えるが，アルカリや酸化猟等に対し ては余り適当でない。補強したポリエステル類はパイプ, 管路工事, 自立タンク等に使用される。ポリエステルは 前述のプラスチックスの多くのものと異り熱硬化性であ るから, 一度加熱すると, 熱や圧力では再び軟化させる ことができない。（他の熱硬化性プラスチックスはフェ ノール, ユレア, メラミンおよびフラン等のプラスチッ クスである。)

\section{ユレアおよびメラミン樹脂類}

ユレアとホルムアルデヒドを縮合させて生ずる樹脂質 の材料は 1920 年に John により開発された技術を応用 せるもので, 1928年に商用化されるに至った。熱に比較 的耐える製品は約 10 年の後 Talbotにより実用化され たものでュレアの代りにメラミンが使用されている。両 致，若干の溶剤および多くの塩類に耐える。これら は化学的抵抗性構成材料には余り広くは使用されてない。

\section{フェノール樹脂類}

前述の如く, フェノール樹脂は 1908 年に Baekeland により商業化されたもので, 本質的には石炭酸とホルム アルデヒドとのアルカリ乃至酸縮合物である。 2 洒フェ ノール,レゾルシノール乃至カシューの果実油のような フェノール置換物はそれぞれ速硯性, 接着性乃至可撓性 の製品が得られる。フルフラールはまたホルムアルデヒ ドの代りに使用することが可能である。

遊離の水酸基を含むフェノール樹脂はアルカリに侵さ れる。しかしこれらは塩類, 多くの溶剤, および非酸化 性酸に著しい抵抗性を有する。

フェノール樹脂は加熱塗装, 成型粉, 注型用樹脂およ び接合剤等に使用される。

\section{エポキシ 樹脂 類}

ビスフェノールとェピクロルヒドリンとの反応生成物 をエポキシ樹脂と称し，遊離のフェノール基を含まない るので耐アルカリ性である。これはまた接着性がすぐれ，
塩類, 多くの溶偊，非酸化性酸等に耐える。エポキシ樹 脂は触媒を用いた常温の塗装，接合剤および加熱硬化の 塗装, 注型並びに接合剤に使用される。

\section{フラン 類}

フルフラール特よびフルフリール・アルコールは酸類 により重合して不熔融の製品を生じ，化学薬剤によく耐 えるものが得られる。特殊の接合剤, 管, および化学抵 抗性構成材料にしばしば使用される。これらのものはア セトンとフルフラールより作られるものと共にフランと 総称される。この分類には十分なデータがないので, 製 品の区別は経験のある化学者だけしかできない。防蝕技 術者にとり幸なことには，フラン類は何れも全部，熱， 塩類, 溶隹, 非酸化性酸類に耐える。しかし, いわゆる フラン接合剤は塩素, 次覀塩素酸ソーダ, 硝酸, クロム 酸, 濃硫酸, およびその他の酸化剤には侵される。

要 約

非金属の構成材料を選択するに当り，プラスチックス に関する過去の経験や進行中の試験計画等に代る資料の ない場合には，その分子構造を検討することが極めて有 力な助けである。プラスチックスに関する基礎的知識を 適正に応用すれば試験結果を誤って解勫するのを防止で きるはずである。若し, 特定の材料に関する実際の試験 結果が予想と完全に矛盾すれば，その使用方法と可能な 配合物の非抵抗性等を十分検討すべきである。この文章 にある情報は, 検討せんとするプラスチックス本来の性 質が知れてない限り，有効に利用することができないの は明らかである。

\section{参考 交献}

Protctive and Decorative Coatings, Joseph J. Matiello, Vol. I. John Wiley \& Sons, 1941.

The Chemistry of Synthetic Resins, Carlton Ellis, Reinhold Publishing Co., 1935

Chemistry of Commercial Plastics, K.I. WakeMan, ReinhoId Publishing Co., 1947.

Handbook of Plastics, $H$. R. Simonds, D. Van Nostrand Co. Inc., 1943.

An Introduction to Engineering Plastics, D. W. Brown \& W. T. Harris, Murrsy Hill Book Co. Inc., 1947.

Modern Plastics Encyclopedia and Engineerings Handbook. Issued annually by Plastics Catalog Corp.

Synthetic Resins and Rubbers. P. O. Powers, John Wiley \& Sons. Inc., 1943. 